\title{
WATER UPTAKE BY Annona diversifolia SAFF. AND A. purpurea MOC. \& SESSÉ EX DUNAL SEEDS (ANNONACEAE) ${ }^{1}$
}

\author{
GISELA FERREIRA², ALMA ROSA GONZÁLEZ ESQUINCA ${ }^{3}$ IVAN DE-LA-CRUZ-CHACÓN ${ }^{4}$
}

\begin{abstract}
Annonaceae seeds are known by presenting dormancy mechanisms, whose reports ranging from coating impermeable to the physiological dormancy. By this way, the present study aimed to evaluate water uptake in Annona diversifolia Saff and Annona purpurea Moc \& Sessé ex Dunal seeds. For this study, seeds were placed under immersion in distilled water, and used four replicates of 25 seeds of each species, which were weighed during the 480 hours that were immersed. To determine the place of purchase of water, Annona diversifolia seeds were sealed with paraffin at different locations. Based on the results, seeds from both species reached the phases I and II of water uptake, which indicates they are not hard; however, germination (Phase III) was not reached. Annona diversifolia seeds completed Phase I with, 50h and Annona purpurea with $70 \mathrm{~h}$ from imbibitions begin, which shows that even slowly, water is acquire.
\end{abstract}

Index terms: Annonaceae, propagation, seed dormancy, imbibition.

\section{AQUISIÇÃO DE ÁGUA EM SEMENTES DE Annona diversifolia SAFF. E A. purpurea MOC. \& SESSÉ EX DUNAL (ANNONACEAE)}

RESUMO - As sementes de espécies da família Annonaceae são conhecidas por apresentarem mecanismos de dormência, cujos relatos vão desde a impermeabilidade do tegumento até a dormência fisiológica. Neste sentido, o objetivo do presente trabalho foi avaliar a impermeabilidade à água das sementes de Annona diversifolia Saff e Annona purpurea Moc \& Sessé ex Dunal a partir do estudo da curva de aquisição de água. Para a realização do estudo, sementes foram colocadas sob imersão em água destilada, sendo utilizadas 4 repetições de 25 sementes de cada espécie, as quais foram pesadas durante as 480 horas em que ficaram imersas. Para determinar o local de aquisição de água, sementes de Annona diversifolia foram vedadas em diferentes locais com parafina. Com base nos resultados, pode-se afirmar que sementes de ambas as espécies apresentam Fase I e II da germinação, o que indica que as sementes não são impermeáveis; contudo, a Fase III não é alcançada. As sementes de Annona diversifolia completam a Fase I com 50 horas, e as de Annona purpurea, com 70 horas do início da embebição, o que demonstra que, mesmo de maneira lenta, a água é adquirida.

Termos para indexação: Anonáceas, propagação, dormência de sementes, embebição.

\footnotetext{
${ }^{1}$ (Trabalho 210-13) - Recebido em: 20-05-2013. Aceito para publicação em: 10-12-2013. V Congresso Internacional \& Encontro Brasileiro sobre Annonaceae: do gene à exportação (19 a 23 de Agosto). Parte da Convenio UNESP-UNICACH. Parte de Pos-doc do primeiro autor realizado na UNICACH. Bolsa de Pos-doc CAPES.

${ }^{2}$ Prof $f^{a}$ Adjunto da UNESP, Depto Botânica, IBB, Botucatu-SP, Brasil. CP: 510, Rubião Junior,.tel (14-3880-0124)E-mail: gisela@ ibb.unesp.br

${ }^{3}$ Researcher. Dr ${ }^{\mathrm{a}}$, Faculdade de Ciências Biológicas-UNICACH - Universidad de Ciencias y Artes de Chiapas, Tuxtla Gutierrez, Chiapas, México. E-mail: aesquinca@unicach.mx

${ }^{4}$ Prof. Dr., Faculdade de Ciências Biológicas - UNICACH-, México, E-mail: ivan.cruz@unicach.mx
} 


\section{INTRODUCTION}

To meet the market demand to fruits of the Annonaceae family are necessary areas of high productivity, which begins with the propagation of seedlings, derived from productive clones. The propagation method most used in Annonaceae is grafting, in which one rootstock is formed from seeds (BARON et al., 2013, LEMOS et al., 2013). Thus, it is a constant search for alternative species such as Annona diversifolia Saff and Annona purpurea Moc $\&$ Sessé ex Dunal, that are potential species to be used in the expansion of production areas as rootstock to other Annonaceous, so as for in natura consumption, food industry or to discoveries of new molecules for pharmaceutical industry (LUNA-CAZARES et al., 2006; LOBO et al., 2007; DE-LA-CRUZ et al., 2012). However, Annonaceae seeds are known to have different types of dormancy. There are reports of morphophysiological dormancy (BASKIN Y BASKIN, 1998), presence of rudimentary embryo (SMET et al., 1999) and problems of impermeability teguments (SVOMA, 1998; SMET et al., 1999).

Some studies to overcome seed dormancy with the application of plant growth regulators are been done in Annonaceae (SMET et al., 1999; FERREIRA et al., 2002; LIMA-BRITO et al., 2006; SILVA et al., 2007; BRAGA et al., 2010; OLIVEIRA et al., 2010; COSTA et al., 2011; CORSATO et al., 2012) and in this cases are necessary to determine the time of immersion treatments in the solutions, which is made from the elaboration of the acquisition water curve. Furthermore, obstructions on purchase of water by seeds are also detected with the completion of this curve, as well as times of osmotic conditioning (VARIER et al., 2010).

During the acquisition of water by seeds, metabolic processes are activated, in order to provide energy for the resumption of embryo development (BEWLEY et al., 2013). The beginning of water input by seeds, called Phase I of germination or soaking is characterized by rapid acquisition of water, as a result of a high water potential gradient between the seed and the environment, mainly caused by the low matric potential seed (HILHOST, 2007). With the increased free water availability and metabolism in the seed, the matric potential leaves to be responsible for the water entry into the seed, which indicates entry into Phase II of the curve, lag phase. In Phase II, therefore, is when all matrices reach full hydration, the matric potential becomes zero and the osmotic potential becomes responsible for the movement of water into the seed (BEWLEY et al., 2013).
During Phases I and II of the acquisition of water, enzymes are synthesized and activated in response to hormonal activity (GUBLER et al., 2005). Thus, the entry of water in quiescent seeds occurs together with the new synthesis of hormones, such as gibberellins, and enzymes like $\alpha$-amylase, which act on the storage material degradation (KUCERA et al., 2005; YAMAGUCHI, 2008; TAIZ; ZEIGER, 2013). According to Nonogaky et al. (2010) is during this phase that the genetic regulators of germination act, either to promote or inhibit entry into Phase III, whereas seeds that don't produce gibberellins do not complete germination. Thus, seeds with physiological or morphophysiological dormancy can sustain a low level of metabolic activity and Phase II can be prolonged for months or years (HILHORST, 2007).

In this context becomes evident the importance of understanding the acquisition of water phases to facilitate the detection of dormancy mechanisms related with the wither control and also in determining the time to pre-germination treatments in solutions with plant growth regulators or osmotic conditioning.

Thus, the hypothesis to be tested in this experiment is that seeds of Annona diversifolia and A. purpurea are not hard (water impermeable), perform Phases I and II of germination, but even with the purchase of water and considering that seeds are dormant, do not complete germination (Phase III).

\section{MATERIAL AND METHODS}

Fruits of Annona diversifolia Saff. (papausa) and Annona purpurea Moc \& Sessé ex Dunal (chincuya) were obtained in home orchards, and in local markets in the city of Tuxtla Gutiérrez, Chiapas, Mexico. The seeds were manually extracted under running water and immersed in a solution of sodium hypochlorite, $10 \%$ (i.a.) for 5 minutes, rinsed with distilled water and kept on filter paper in a laboratory bench at $25^{\circ} \mathrm{C}$ $\left(+2{ }^{\circ} \mathrm{C}\right)$ for seven days to surface drying.

The water content of the seeds was determined employing four replications of 25 seeds, by the method of drying at $105{ }^{\circ} \mathrm{C}$ for 24 hours (BRASIL, 2009). The tetrazolium test to assess the viability of the seeds was performed in four replicates of 25 seeds at the beginning and end of the test. The treatments consisted of the times in which the seeds remained immersed in distilled water, in order to determine the three phases of the acquisition water curve. After determining the initial moisture content of the seed lot, four replicates of 25 seeds were placed in 
beckers containing distilled water with aeration and maintained in an incubator brand CONVIRON ${ }^{\circledR}$ at $30{ }^{\circ} \mathrm{C}\left( \pm 2{ }^{\circ} \mathrm{C}\right)$, relative humidity 50 to $60 \%$ in the absence of light.

The weight measurements were taken every hour, for eight hours $(\mathrm{h})$, and after $8 \mathrm{~h}$ were performed at $24 \mathrm{~h}$ and $32 \mathrm{~h}$. The weight continued every $8 \mathrm{~h}$ until reaching 120 hours of immersion and, after, every $24 \mathrm{~h}$ to $480 \mathrm{~h}$ of immersion. In each time, the seeds were removed from the containers, weighed and returned. The water was replaced in each evaluation and maintained oxygenation with aquarium pumps. With the weighing data were calculated water content of the seeds over time, considering the moisture content obtained before immersion of the seeds in the treatment (Time $=0$ ), after four hours of soaking, and so forth, up to $480 \mathrm{~h}$ of immersion. The results are shown in moisture content (\%) in relation to the initial mass of dry matter (BRASIL, 2009).

To study the variation in water content was adjusted logistic equation model $\mathrm{y}=\mathrm{a} /[1+\exp$ $\left(\mathrm{b}-\mathrm{c}^{*} \mathrm{x}\right)$ ], with $\mathrm{y}=$ moisture content $(\%), \mathrm{x}=$ time (in hours). To calculate the change in Phase I to Phase II of water acquisition was used the calculation of asymptotic point of deceleration (PDA), as proposed by Mischan et al. (2011).

To determine the location where the water is acquired it was used $A$. diversifolia seeds as model. They were divided into five groups of 100 seeds, each were sealed (obturated) with paraffin as follows: uncovered seed; total obturated seeds, uncovered seed coat (seeds with the hilum obturated); seeds with hilum and suture (rafe-antirafe) obturated; seeds only with hilum uncovered. All groups were placed in distilled water ( $\mathrm{pH} 6.5$ ) at $30{ }^{\circ} \mathrm{C}$ and relative humidity of 50 to $60 \%$ in the absence of light within a germinator CONVIRON $^{\circledR}$ and were weighed for periods of 0,1 , 2, $3,4,7,23,47,56,72,80$ and 96 hours. Results are expressed as the average of three repetitions in percentage water gained per gram of seed.

\section{RESULTS AND DISCUSSION}

From the calculations proposed by Mischan et al. (2011) was possible to establish the end of Phase I of water acquisition, with determining the asymptotic point of deceleration. This point indicates the approximate value, when there is a reduction in acquisition rate of water by the seed, indicating that the matric potential approaches zero, resulting in the stability of water acquisition by Annona diversifolia Saff. and A. purpurea Moc \& Sessé ex Dunal (Figures 1 and 2 respectively) and that entered into Phase II seed germination.

Phase I of the water acquisition (imbibition) lasted approximately 50 hours in seeds of $A$. diversifolia and seeds which had an initial moisture content of $9.04 \%$ (before the start of imbibition) reached $31.16 \%$ water content at the end of this phase. The same pattern of response was observed in seeds of A. purpurea, which had an initial moisture content of $16.54 \%$, and reached the stability curve around 70 hours, with a water content of $31.18 \%$ (Figures 1 and 2).

The acquisition of water by the seeds occurs due to the difference between the water potential of these and the environment and, bigger the difference, faster the rate of imbibition. In this case, the first acquisition phase of water (Phase I) tends to be rapid and should last for 1 to 2 hours (BEWLEY et al., 2013). To Marcos Filho (2005) Phase I occurs for eight to sixteen hours, reaching moisture content exceeding $45 \%$ in cotyledon seeds $30-35 \%$ in endospermatic seeds. And yet, according to Carvalho and Nakagawa (2000) between one and two hours seeds complete Phase I, achieving the water content ranging between $35 \%$ and $40 \%$ for cotyledons seeds and $25 \%$ and $30 \%$ for endospermatic seeds.

The species in this study showed slowly water acquisition, over that proposed by Bewley et al. (2013) which suggest the duration of one to two hours to the Phase I. It is noted that, while A.diversifolia and $A$. purpurea seeds presenting Phase I duration of about 50 and 70 hours, respectively, Ferreira et al. (1997) observed that $A$. squamosa L. seeds stabilized the water uptake with approximately 5 hours of immersion while, at 12 hours, atemoya seeds (A.cherimola $\mathrm{x}$ A. squamosa) continued in Phase I. Subsequently, Ferreira et al. (2006) determined Phase $\mathrm{I}$ in atemoya seeds (A. cherimola $\mathrm{x}$ A. squamosa) lasting 30 to 36 hours. Moreover, in a study of Annona emarginata seeds, Costa et al. (2011) found that to complete Phase I were required 60 to $72 \mathrm{~h}$ of imbibition (Table 1).

It should be noted that, regardless of the seeds moisture content, Phase I was completed, in both species, when water content was achieved of approximately $31 \%$, regardless of the time taken to reach this water content. In this case, $A$. diversifolia imbibes water faster than A. purpurea. Thus, it is evident that the change from Phase I into Phase II is characterized by water content reached and not according to the time taken to reach it. Likewise Costa et al. (2011) also obtained $27.85 \%$ and $28.35 \%$ water content in seeds of $A$. emarginata when completed Phase I (Table 1). These observations are consistent with that proposed by Carvalho and 
Nakagawa (2000) since the authors reported that the curve stabilization takes place when the reached moisture content about 25 to $30 \%$ and by Marcos Filho (2005) of 35\%, in endospermatic seeds. In the case of Annona seeds this ratio could be related to the lipid and ruminate characterist of the endosperm, so the imbibed water could be deposited, in the beginning, between the ruminations caused by the disposal of tegmen.

However, several factors must be considered, such as the resistance by the seed tegument to water entry, the reserves composition, and the environmental conditions at the time of imbibition (BEWLEY et al., 2013).

The acquisition rate of water by Annonaceae seeds may be related to the resistance imposed by the seed tegument, which does not mean that no water is absorbed. As proposed by Svoma (1998) and Smet et al. (1999) Annonaceae seeds have a tegument composed of a woody waterproof cover, indicating that water can penetrate only through the seed hilum, through the micropyle. Another factor that may have resulted in slower acquisition of water by Annonaceae seeds is the largest proportion of lipids in their reservations, about the proteins and sugars (CORSATO et al., 2012). However, contrary to what has been proposed by Svoma (1998) and De Smet et al. (1999) about the impermeability of the covering, the results with wax indicate that at least in A.diversifolia there is no impediment to the entry of water into the seed, since water enters through different sites, mainly through the seed coat (testa), the testa suture (rafe-antirafe), and fewer by hilummicropyle (Figure 3).

With the end of Phase I, lasting $50 \mathrm{~h}$ for $A$. diversifolia seeds and $70 \mathrm{~h}$ for $A$. purpurea seeds, Phase II was initiated, that was observed up to 480 $\mathrm{h}$ from start of immersion.

In Phase II, water acquisition becomes almost zero, because reductions in water potentials of seed are mainly dependente of decreasing in osmotic potential, which in turn, depends on the metabolic activity initiated in Phase I, when the large molecules are degraded lowering the osmotic potential of the environment (BEWLEY et al., 2013). The seeds in this study remained $430 \mathrm{~h}$ and $410 \mathrm{~h}$ (A. diversifolia and A. purpurea, respectivily) on Phase II and did not reach the visible germination, which suggests the presence of some dormancy control. Other important information is that the seeds were alive during the experimental time according tetrazolium test.

When the seeds have physiological or morphophysiological dormancy, the duration of Phase II can be extended (HILHORST, 2007), which seems to have occurred in this study, since no visible germination was observed (Phase III) after 20 days of assessment. The fact that $A$. diversifolia and $A$. purpurea seeds were alive and did not reach Phase III, indicates the existence of some germination control, as also proposed by Albornoz et al. (2006) in relation to $A$. purpurea, and by González-Esquinca et al. (1997) in relation to $A$. diversifolia seeds reporting the need for six to eight months of storage to overcome dormancy. 


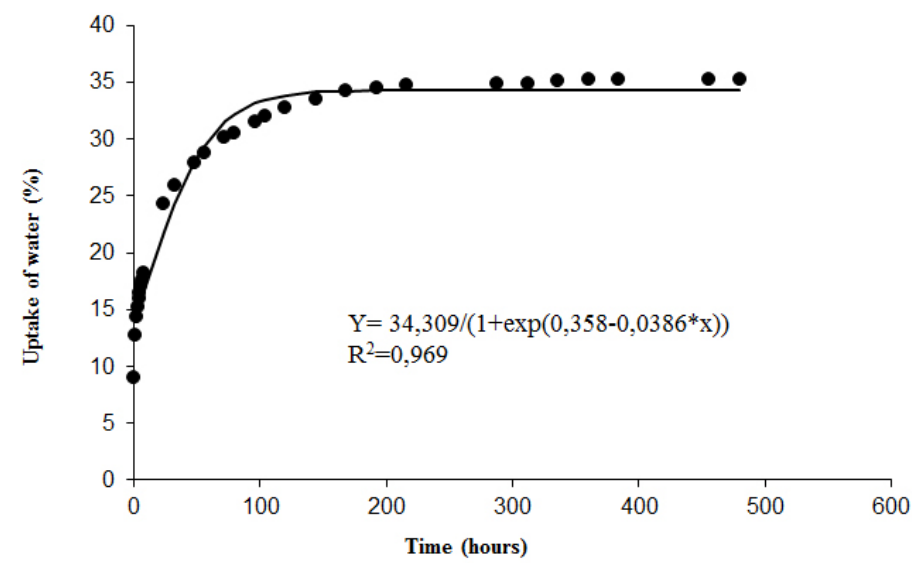

FIGURE 1-Pattern acquisition of water in Annona diversifolia Saff. seeds.

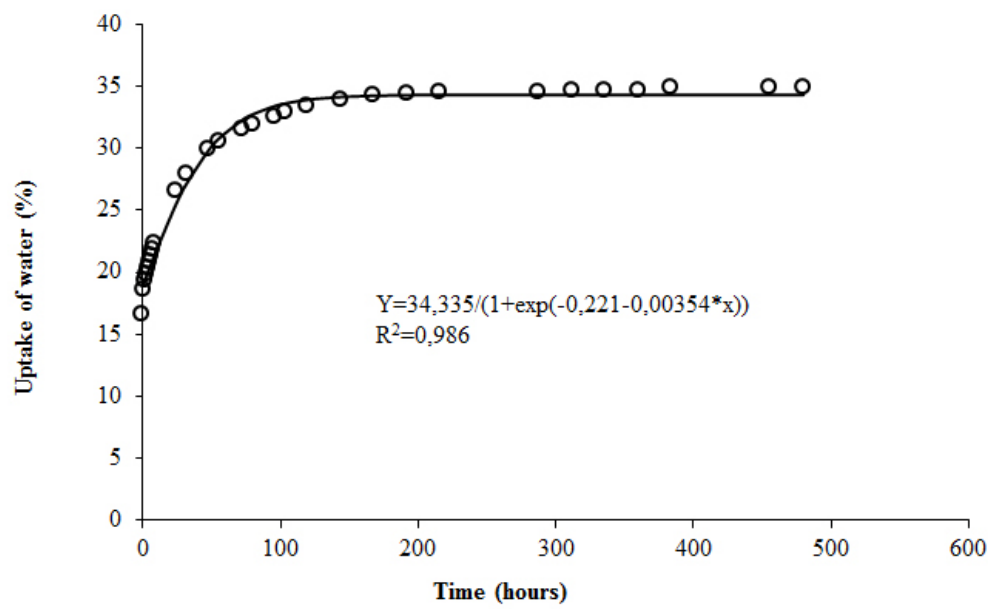

FIGURE 2. Pattern acquisition of water in A. purpurea Moc. \& Sessé ex Dunal seeds.
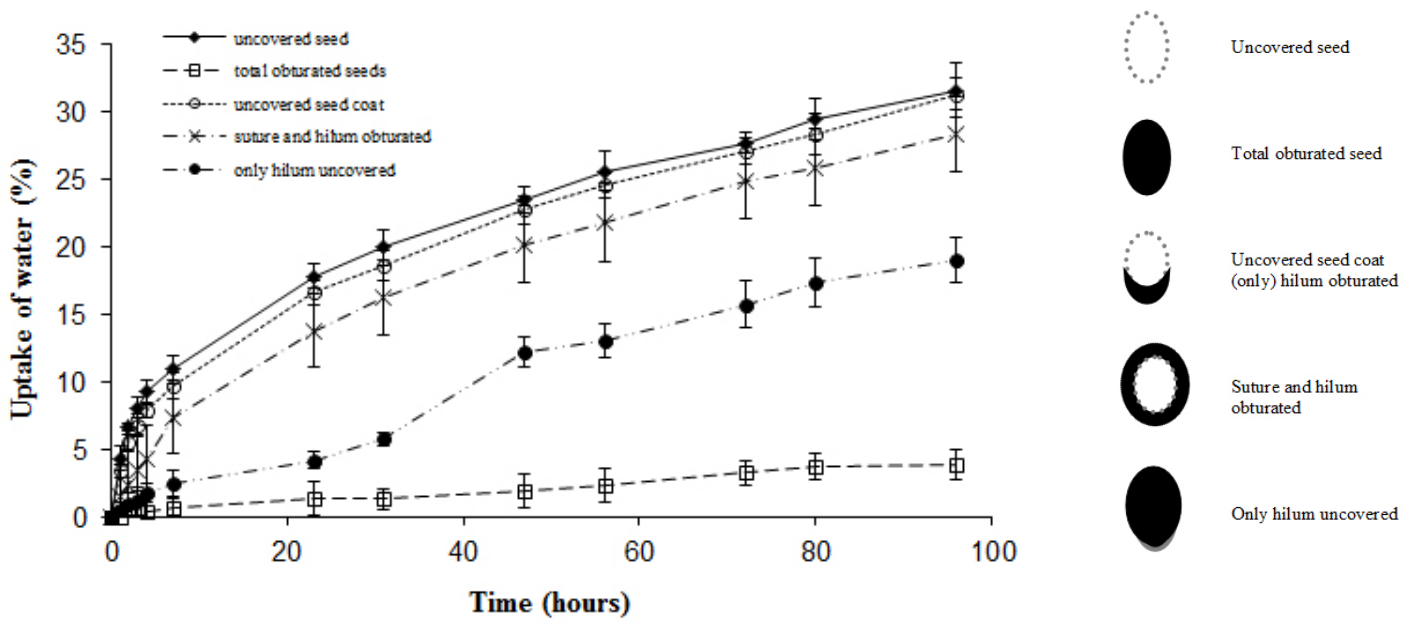

FIGURE 3- Places of water acquisition in Annona diversifolia Safford seeds. 
TABLE 1- Characteristics of pattern acquisition of water in some Annonaceae seeds.

\begin{tabular}{|c|c|c|c|c|c|c|}
\hline Specie & $\begin{array}{l}\% \text { Initial } \\
\text { water }\end{array}$ & $\begin{array}{l}\% \text { Final } \\
\text { water }\end{array}$ & $\begin{array}{c}\text { Phase I } \\
\text { duration (h) } \\
\psi_{\mathrm{m}}=0\end{array}$ & $\begin{array}{l}\text { Acquisition rate } \\
\text { of water } \\
\left(\mathrm{g} \mathrm{H}_{2} \mathrm{O}^{-1} \mathrm{~g} \mathrm{sem}^{-1}\right) \\
\end{array}$ & $\begin{array}{l}\text { Morfological/Physiological } \\
\text { characteristics of seeds }\end{array}$ & Reference \\
\hline A. squamosa & & & 92 & & Permeable seed & Ferreira et al., 1997 \\
\hline $\begin{array}{l}\text { A. cherimola } \mathrm{x} \\
\text { A. squamosa }\end{array}$ & 11 & 20 & $27-47$ & $0.19-0.33$ & $\begin{array}{c}\text { Permeable seed, } \\
\text { Physiological dormancy }\end{array}$ & $\begin{array}{c}\text { Ferreira et al., } 1997 \\
\text { Ferreira et al., } 2006 \\
\text { Braga et al., } 2010\end{array}$ \\
\hline A. emarginata & 10 & 30.9 & $60-72$ & 0.27 & $\begin{array}{l}\text { Permeable seed, } \\
\text { tendency to be orthodox, } \\
\text { low storage capacity }\end{array}$ & $\begin{array}{l}\text { Iassia et al., } 2011 \\
\text { Costa et al., 2011; } \\
\text { Corsato et al., } 2012\end{array}$ \\
\hline A. diversifolia & 9.04 & 31.16 & 50 & 0.4424 & $\begin{array}{c}\text { Permeable seed, } \\
\text { physiological dormancy }\end{array}$ & Ferreira et al., 2013 \\
\hline A. purpurea & 16.54 & 31.18 & 70 & 0.2091 & $\begin{array}{c}\text { Permeable seed, } \\
\text { physiological dormancy }\end{array}$ & Ferreira et al., 2013 \\
\hline
\end{tabular}

\section{CONCLUSION}

Annona diversifolia Saff and A. purpurea Moc \& Sessé ex Dunal are not impermeable seeds, because they present Phase I and II of germination well characterized, although the acquisition of water takes place slowly and do not reach to Phase III. The slow water acquisition appears to be a characteristic of Annonaceae seeds.

\section{REFERENCES}

ALBORNOZ, G. F. G.; MARTÍNEZ, R.; LEZAMA, E.V.; ANDRADE, L.M.M.; SOLÍS, J.M.; CURIEL, A. Pruebas de envejecimiento acelerado en semillas de chincuya (Annona purpurea Moc \& Sessé). I. Germinación. In: CONGRESO NACIONAL DE ANONÁCEAS, 3., 2006,Villahermosa, México. Memoria... Villahermosa: Universidad Juárez Autônoma de Tabasco, 2006. p. 48.

BARON, D.; FERREIRA, G.; RODRIGUES, J.D.; BOARO, C.S.F.; MACEDO, A. C. Gas exchange, phisiological indexes and ionic accumulation in Annona emarginata (Schltdl.) H. Rainer seedlings in nutrients solution. Revista Brasileira de Fruticultura, Jaboticabal, v.35, n. 3. p. 361-376, 2013.

BASKIN, C. C.; BASKIN, J. M. Seeds: ecology, biogeography and evolution of dormancy and germination. San Diego: Academic Press, 1998. $666 \mathrm{p}$.
BEWLEY, J.D.; BRADFORD, K.J.; HILHORST, H.W.M.; NONOGAKI, H. Seeds: physiology of development, germination and dormancy. $3^{\text {rd }}$ ed. New York: Springer, 2013. 392p.

BRAGA, J. F. ; FERREIRA, G.; PINHO, S.Z.; BRAGA, L.F.; SOUSA, M.P. Germination of atemoya (Annona cherimola Mill. x A. squamosa L.) CV. Gefner seeds subjected to treatments with plant growth regulators. International Journal of Science and Nature, Daca, v.1, n. 2, p. 120-126, 2010.

BRASIL. Ministério da Agricultura. Regra de análise de sementes. Brasília: Departamento de Produção Vegetal, 2009. 398 p.

CARVALHO, N. M.; NAKAGAWA, J. Sementes: ciência, tecnologia e produção. 4. ed. Jaboticabal: FUNEP, 2000. 588 p.

CORSATO, J.M.; FERREIRA, G.; BARBEDO, C.J. Desiccation tolerance in seeds of Annona emarginata (Schltdl.) H. Rainer and action of plant growth regulators on germination. Brazilian Journal of Plant Physiology, Campos dos Goytacazes, v.24, n. 4, 2012.

COSTA, P. N.; BUENO, S.S.C.; FERREIRA, G. Fases da germinação de sementes de Annona emarginata (SCHLTDL.) H. Rainer em diferentes temperaturas. Revista Brasileira de Fruticultura, Jaboticabal, v. 33, n. 1, p. 253-260, 2011. 
DE LA CRUZ CH., I; GONZÁLEZ-ESQUINCA, A. R. Liriodenine alkaloid in Annona diversifolia during early development. Natural Product Research, London, v. 26. n. 1, p. 42-49, 2012.

FERREIRA, G.; GUIMARÃES, V.F.; PINHO, S.Z.; OLIVEIRA, M.C.; RICHART, A.; BRAGA, J.F.; DIAS, G.B.Curva de absorção de água em sementes de atemoia (Annona cherimola MILL. x Annona squamosa L.) CV. 'Gefner'. Revista Brasileira de Fruticultura, Jaboticabal, v. 28, n. 1, p. 121-124, 2006.

FERREIRA, G.; CEREDA, E.; SILVA, C.P.; CUNHA, R.J.P.; CATANEO, A. Imbibition studies of sugar apple (Annona squamosa L.) and atemoya (A. squamosa $x$ A. cherimola Mill.) seeds. In: CONGRESSO INTERNACIONAL DE ANONÁCEAS, 1., 1997, Chapingo, México. Memorias... Chapingo: Universidad de Chapingo, 1997. p. 210-224.

FERREIRA, G.; ERIG, P.R.; MORO, E. Uso de ácido giberélico em sementes de fruta-do-conde (A. squamosa L.) visando à produção de mudas em diferentes embalagens. Revista Brasileira de Fruticultura, Jaboticabal, v. 24, n. 1, p. 178-182, 2002.

FERREIRA, G; GIMENEZ, J.I.; CORSATO, J.M.; OLIVEIRA, M.C. Germinação de sementes de anonáceas. In: FERREIRA, G.; KAVATI, R.; BOARO, C.S.F.; FERRARI, T.B.; LEONEL, S. Anonáceas: propagação e produção de mudas. Botucatu: Fepaf, 2013. p.19-43.

GONZÁLEZ-ESQUINCA,A.R.; LUNACAZARES, L.M.; ALVAREZ MOCTEZUMA, J.G.; DE PAZ VELAZCO, Y. Estudios sobre el letargo de Annona diversifolia Saff (Annonaceae). In: CONGRESO INTERNACIONAL DE ANNONÁCEAS, 1., 1997, Chapingo, México. Memorias... Chapingo: Universidad de Chapingo, 1997. p. 229-239.

GIMENEZ, J.I.; CORSATO, J.M; FERREIRA, G.; PINHO, S.Z. Curva de adquisición del agua en semillas de Annona emarginata (Schltdl) H. Rainer sometidas al condicionamiento osmótico. In: GONZÁLEZ-ESQUINCA, A.R., LUNACAZÁRES, L.M., GUTIÉRREZ-JÍMENEZ, J.; SCHLLIE-GUZMAN, M.A; VIDAL-LÓPEZ, D.G.; Anonáceas: plantas antiguas, estudios recientes. Tuxtla Gutiérrez. UNICACH, 2011.p.237-304
GUBLER, F.; MILLAR, A.A.; JACOBSEN, J.V. Dormancy release, ABA and pre-harvest sprouting. Current Opinion in Plant Biology, Saint Louis, n. 8, p. 183-187, 2005.

HILHORST, H. W. M. Are dormant seeds lazy and germinating seeds not? In: ADKINS, S .W.; NAVIE, S. V.; ASHMORE, S. Seeds: biology, development and ecology. Cambridge: CABI, 2007. p. 188-194.

KUCERA, B.; COHN, M. A.; LEUBNERMETZGER, G. Plant hormone interactions during seed dormancy release and germination. Seed Science Research, Wallingford, n. 15, p. 281-307, 2005.

LEMOS E.E.P. Bases anatômicas e aspectos fisiológicos da enxertia em anonáceas. In: FERREIRA, G.; KAVATI, R.; BOARO, C.S.F.; FERRARI, T.B.; LEONEL, S. Anonáceas: propagação e produção de mudas. Botucatu: Fepaf, 2013.p.45-58.

LIMA-BRITO, A.; CAMPOS, V.C.A.; SANTANA,J.R.F.; DORNELLES, A.L.C. Efeito do ácido giberélico $\left(\mathrm{GA}_{3}\right)$ na emergência de plântulas de Annona crassiflora Mart., Annona squamosa L. e Annona muricata L. Magistra, Cruz das Almas, v. 18, n. 1, p. 27-33, 2006.

LOBO, M.; DELGADO, Ó.; CARTAGENA, J.; FERNANDEZ, E.; MEDINA, C. Categorización de la germinación y la latencia en semillas de chirimoya (Annona cherimola L.) y guanábana (Annona muricata L.), como apoyo a programas de conservación de germoplasma. Agronomía Colombiana, Bogotá, v. 25, n. 2, p. 231-244, 2007.

LUNA-CAZÁRES L.M, DE LA CRUZ CH I, . GONZÁLEZ-ESQUINCA, A.R.. Usos de Annona purpurea Mociño \& Sessé ex Dunal. In: CONGRESO NACIONAL DE ANONÁCEAS, 3., 2006, Villahermosa, México. Memoria... Villahermosa: Universidad Juárez Autónoma de Tabasco, 2006. p. 61.

MARCOS FILHO, J. Fisiologia de sementes de plantas cultivadas. Piracicaba: Fealq, 2005. 495 p.

MISCHAN, M. M.; PINHO,S.Z.; CARVALHO,L.R. Determination of a point sufficiently close to the asymptote in no linear growth functions. Scientia Agricola, Piracicaba, v. 68, n. 1, p. 103-114, 2011. 
NONOGAKI, H.; BASSEL,G.W.; BEWLEY,J.D. Germination - still a mystery. Plant Science, Limerick, v. 179, p.574-581, 2010.

OLIVEIRA, M. C.; GUIMARÃES, V.F.; DIAS, G.B. Germinação de sementes de atemoia (Annona cherimola Mill. x A. squamosa L.) CV. 'Gefner' submetidas a tratamentos com ácido giberélico $\left(\mathrm{GA}_{3}\right)$ e ethephon. Revista Brasileira de Fruticultura, Jaboticabal, v. 32, n. 2, p. 544-554, 2010.

SILVA, E. A. A.; MELO, D.L.B.; DAVIDE, A.C.; BODE, N.; ABREU, G.B.; FARIA, J.M.R.; HILHORST, H.W.M. Germination Ecophysiology of Annona crassiflora seeds. Annals of Botany, London, v. 99, p. 893-830, 2007.

SMET, S. D. E.; DAMME, P.V.; SCHELDEMAN, $\mathrm{X}$.; ROMERO, J. Seed structure and germination of cherimoya (Annona cherimola Mill.). Acta Horticulturae, The Hague, n. 497, p. 269-278, 1999.
SVOMA, E. Seed morphology and anatomy in some Annonaceae. Plant Systematics and Evolution, New York, n. 209, p. 177-204, 1998.

TAIZ, L.; ZEIGER, E. Fisiologia vegetal. 5.ed. Porto Alegre: Artmed, 2013. 954p.

VARIER, A.; VARI, A.K.; DADLANI,M.The subcellular basis of seed priming. Current Science, Bangalore, v.99, n.4, p. 450-456, 2010.

YAMAGUCHI, S. Gibberellin metabolism and its regulation. Annual Review of Plant Biology, Palo Alto, v. 59, p. 225-251, 2008. 